\title{
ASSESSMENT OF PARTICIPATORY AGRO FORESTRY INTERVENTIONS IN INTEGRATED WATERSHED MANAGEMENT
}

\author{
H M P B Vidyaratne ${ }^{1}$ and C M Wijayaratne ${ }^{2}$ \\ ${ }^{1}$ Central Environmental Authority \\ 2International Irrigation Management Institute
}

A field study was carried out from march 1997 to December 1997 using direct. field measurements and a questionnaire survey 10 assess Forest Department's and shared Control of Natural Resources (SCOR) Project's agrolorestry inputs and to examine social and institutional aspects concened in planning and implementing agroforestry inputs. Data were collected for two agrolorestry samples and one control where only SCOR made some interventions

Benefit - cost streams of lanmers for each of different items, for unit of land agroforestry plot and NPV of that unit are evaluated by considering timber value of teak and income earned by inter - cropping. Survival rate of teak plantation established both in 1995 and 1996 years was between $97 \%-98 \%$.

Individual interviews were carried out to consider social and institutional aspects such as farmer-farmer interactions, farmer officer interactions, problems arisen in co-ordination of relevant line agencies, conflicts and conllict resolution between officers and different institutions. attitudinal change of farmers etc.

Other Institutions involved are: Department of Agriculture, Divisional Secretary Office, Goverument Cooperative shops, Department of Animal Husbandry and Veterinary Science and Coconut Cultivation Board.

Major reasons for arising of conflicts are: knowledge and attitudes of Officers of various institutions are different and objectives of various institutions are different.

Many conflicts had been arisen in relation to distribution of incentives: provided by the Participatory Forcstry Project. (PFP)

Project's benclits included: Reduction of illicit felling, increased knowledge of farmers on conservation farming and environment conservation, significant increase in NPV and acceptable B: C ratio, increased market links for agrolorestry produce etc.

Preceedings of the Fonrth Anmual Forestry and Enviromment Symposinm 1998 of the Departme'ne of Forestry and Envirommental Science, University of Sri Jaye'neardenepura. Sri Lamka 